\title{
On the Role of Transient Eddies in the Tropical Troposphere*
}

\author{
By Tsuyoshi Nitta \\ Geophysical Institute, Tokyo University \\ (Manuscript received 20 January 1970, in revised form 23 May 1970)
}

\begin{abstract}
We studied the contributions of eddies with various time scale to the covariances of the zonal wind component, temperature and geopotential height with the meridional wind component in the tropical troposphere by the spectral analysis of time series data of Pacific stations for April-July 1962. In the equatorial region disturbances with periods near 4 days play an important role in the covariances. On the other hand, disturbances with period near 6 days and those with periods longer than 10 days mostly contribute to the covariances in sub-tropical latitudes (near $20^{\circ} \mathrm{N}$ ).

Average horizontal transports of zonal momentum, sensible heat and potential energy due to transient eddies and partial contributions of disturbances with periods near 4 days to the transports are examined as functions of latitude and altitude. Strong energy fluxes due to disturbances with periods longer than 6 days enter into the tropics from higher latitudes. This results agrees with that obtained theoretically by Mak (1969). Equatorward heat fluxes exist in the lower and the middle troposphere. Large poleward heat fluxes are observed in the upper troposphere. In higher latitudes, contributions of disturbances with periods near 4 days to the horizontal transports are small, but in the equatorial region these become large.

A partial estimate of the energy transformation process of eddies contained between the equator and $15^{\circ} \mathrm{N}$. Large energy fluxes (pressure work) from higher latitudes converge in the equatorial region. The eddy kinetic energy is transformed to the zonal kinetic energy and the eddy available potential energy is transformed to the zonal potential energy. The convergence of energy flux from higher latitudes is one order of magnitude larger than both energy conversions from eddy to zonal energy and from eddy to zonal available potential energy.
\end{abstract}

\section{Introduction}

In recent years, the synoptic-scale wave disturbances in the tropics have been intensively studied by the spectrum analysis of time series data of wind, temperature, geopotential height, etc. Yanai et al. (1968) studied the power spectra of the meridional component of the wind in the tropical Pacific area and found the disturbances with 4-to 5-day periods in the troposphere and in the lower stratosphere. The disturbance in the lower troposphere was related to the "easterly wave" which was previously studied by Riehl (1945, 1948, 1954) and Palmer (1951, 1952). The disturbance in the upper troposphere and the lower stratosphere was identified with the planetary-scale wave which had been discovered by Yanai and Maruyama (1966). Wallace and Chang (1969) also made a spectrum analysis of large-scale

* Division of Meteorology, Contribution No. 187 wave disturbances in the tropical lower troposphere below the 500-mb level. Nitta (1970) examined the average structure of the tropospheric wave disturbances with periods near 4 days in detail by various cross spectrum analyses. These wave disturbances may play an important role in the general circulation in the tropics. Maruyama (1968b) and Yanai and Hayashi (1969) established that the planetary-scale wave found by Yanai and Maruyama (1966) transports the zonal momentum and wave energy upward and the sensible heat poleward.

It has been known that all of the mean motion, transient eddies and standing eddies are important for the general atmospheric circulation in the tropics. The Hadley type circulation is converting mean available potential energy into mean kinetic energy, therefore the Hadley circulation is of great importance for the atmospheric budget of kinetic energy. But because of large errors in determining the mean meridional circulation, 
results of various meridional transports due to the mean motion have not been so reliable. Several authors have shown that standing eddies as well as transient eddies play an important role in various transports in the tropics (Obasi, 1963; Tucker, 1965; Iida, 1968; Kidson et al., 1969).

Starr and White (1952a, b, 1954) examined the eddy transport of zonal momentum in the Northern Hemisphere down to $13^{\circ} \mathrm{N}$ and Obasi (1963) examined them in the southern hemisphere. They showed that the momentum transport due to eddies is generally poleward in the tropics. Besides, Tucker (1965), Iida (1968) and a more recent and extensive study of Kidson et al. (1969) showed that a strong momentum flux in the upper equatorial troposphere is directed from the winter hemisphere to the summer hemisphere. As for the transport of sensible heat, Starr and Wallace (1964) found that there is an equatorward (counter gradient) eddy heat flux at low latitudes. Kidson et al. (1969) also showed equatorward sensible heat flux due to eddies in the middle troposphere in the tropics. In various studies mentioned above statistical quantities due to all the eddies have been obtained but time scales of eddy disturbances contributing to the tropical atmospheric circulation have not been examined. In this study we obtain the eddy transports based on co-spectra between various quantities in the period range of 2 to 20 days at several tropical stations in the Pacific, and examine the typical periods of eddies which may significantly contribute to the general circulation in the tropical atmosphere.

The study of the horizontal transports of the wave disturbances is closely related to the study of the energetics of these disturbances. The mechanism of maintenance of tropospheric wave disturbances in the tropics has not been fully explained partly because of the sparse data in the tropics and partly because of the lack of adequate dynamical models. These wave disturbances have been known to possess the "cold-core" structure in the lower troposphere. Nitta (1970) confirmed this quite clearly by the spectral analysis. Palmer (1951) and Yanai (1961) have suggested that the kinetic energy of the wave disturbances is supplied from the trade easterly current through the horizontal shear. Nitta and Yanai (1969) showed a possibility of the barotropic instability in the trades in the western Pacific. Recently Mak (1969) presented an interesting theory that indicates a possible excitation of the tropical atmosphere driven by stochastic lateral forcing at $\pm 30^{\circ}$ latitudes. On the other hand, Manabe and Smagorinsky (1967) showed that the eddy kinetic energy in a model tropical toposphere is maintained by the conversion from eddy available potential energy in the upper troposphere, which is generated by the release of latent heat of condensation. In a numerical experiment, Krishnamurti (1969) also showed that there is a strong conversion of eddy potential energy to eddy kinetic energy in equatorial latitudes. Recently Yamasaki (1969) has examined the stability of the easterly zonal flow with vertical shear in a conditionally unstable atmosphere and obtained a wave mode which resembles the "easterly waves". This theoretical wave obtains its kinetic energy from the available potential energy due to the latent heat release. In the last part of this paper, a partial estimate of the energy transformations of eddies will be made.

\section{Data and method}

The data used in this study identical with those used in the previous study (Nitta, 1970). We use the data based on special upper observations in the tropical Pacific from 1 April to 31 July 1962. Table 1 shows the list of the upper-air stations. Wind, temperature and geopotential height (or pressure) data are available at an

Table 1. List of stations

\begin{tabular}{|c|c|c|}
\hline Station & Latitude & Longitude \\
\hline Midway & $\mathrm{N} 28^{\circ} 13^{\prime}$ & $\mathrm{W} 177^{\circ} 22^{\prime}$ \\
\hline Lihue & N21 59 & W159 21 \\
\hline Hilo & N19 44 & W15504 \\
\hline Johnston & N16 44 & W169 31 \\
\hline Palmyra & N05 52 & W162 06 \\
\hline Christmas & N02 00 & W157 23 \\
\hline Canton & $\mathrm{S} 0246$ & W171 43 \\
\hline Malden & S 0403 & W155 01 \\
\hline Tutuila & S 1420 & W170 43 \\
\hline Wake & N19 17 & E166 39 \\
\hline Eniwetok & N11 20 & E 16220 \\
\hline Kwajalein & N08 43 & E 16744 \\
\hline Majuro & N07 06 & E 17124 \\
\hline
\end{tabular}

interval of 12 hours at the surface and constant pressure levels of $1000,850,700,500,400,300$, $250,200,150,100,50$ and $30 \mathrm{mb}$. We use a spectral method in order to estimate the horizontal transports of zonal momentum, sensible heat 
and potential energy due to eddies. In order to remove trends with longer periods, we need to apply a high-pass filter to the original data. In earlier studies (Yanai et al., 1968; Nitta, 1970) we used a high-pass filter which conserved the variations only in the period range less than 10 days to pick up the disturbances with periods of 4 to 5 days. But since we need to examine horizontal transports due to various disturbances which may contain periods longer than 10 days, we use a revised high-pass filter which conserves the variations within the period range less than about 20 days. We take 25 as the maximum lag number which gives 51 spectral estimates at an interval of 0.02 cycle per day. The details of computing procedure of the high-pass filter and the spectral analysis were given in Maruyama (1968a).

The covariance between a physical parameter $A$ and the meridional wind component $v$ shows the total horizontal transport of $A$ due to eddies and the co-spectra between $A$ and $v, C_{f}(A, v)$, gives a measure of the northward transport of the quantity $A$ due to the eddies of frequency $f$. As we use spectra of time series data, the trans- port obtained in our analysis is due to the transient eddies, which may include contributions due to "pulsating" stationary waves as well as travelling wave disturbances.

\section{Co-spectra between $u$ and $v, T$ and $v, \phi$ and $v$}

We shall examine the contribution of various disturbances to the covariances of zonal component of the wind $(u)$, temperature $(T)$ and geopotential height $(\phi)$ with meridional wind component $(v)$. We calculate co-spectra between $u$ and $v, T$ and $v$, and $\phi$ and $v$. Since co-spectra at each station are somewhat irregular, we average co-spectra of several stations. We average the co-spectra at Palmyra $\left(6^{\circ} \mathrm{N}, 162^{\circ} \mathrm{W}\right)$, Majuro $\left(7^{\circ}\right.$ $\left.\mathrm{N}, 171^{\circ} \mathrm{E}\right)$ and Kwajalein $\left(9^{\circ} \mathrm{N}, 168^{\circ} \mathrm{E}\right)$ as a group representing the equatorial region. In the lower troposphere, the co-spectra at stations in the Marshall Islands and those at stations in the Line Islands are somewhat different. The negative values of $C(T, v)$ due to 4-day period disturbances are a little stronger in the former region thar in the latter region and the positive values of $C(u, v)$ due to these disturbances are stronger in the former region than in the latter region.

$$
\mathrm{C}(u, v)
$$

LIHUE-HILO-JOHNSTON.WAKE

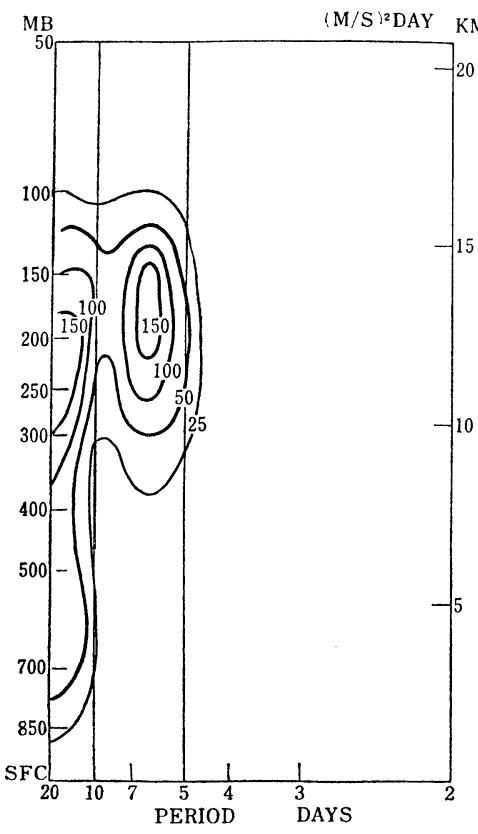

PALMYRA-MAJURO-KWAJALEIN

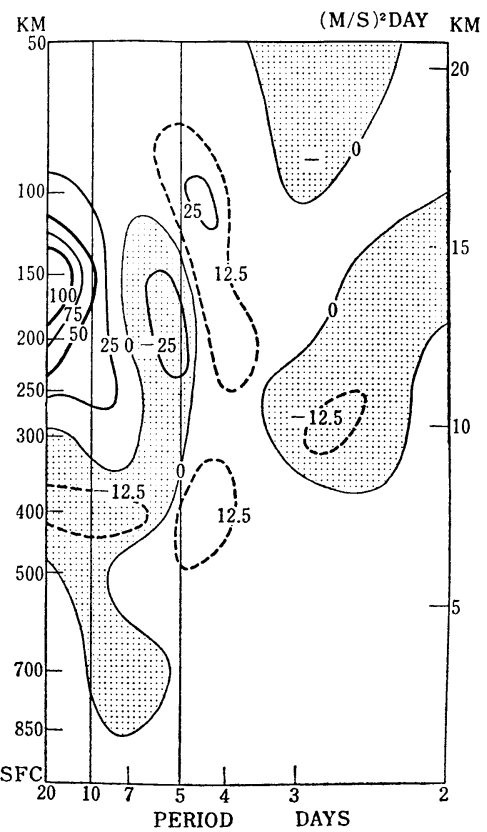

Fig. 1. Average co-spectra between $u$ and $v$ in the sub-tropical region (left) and those in the equatorial region (right). 
$\mathrm{C}(\mathrm{T}, v)$

LIHUE-HILO-JOHNSTON-WAKE

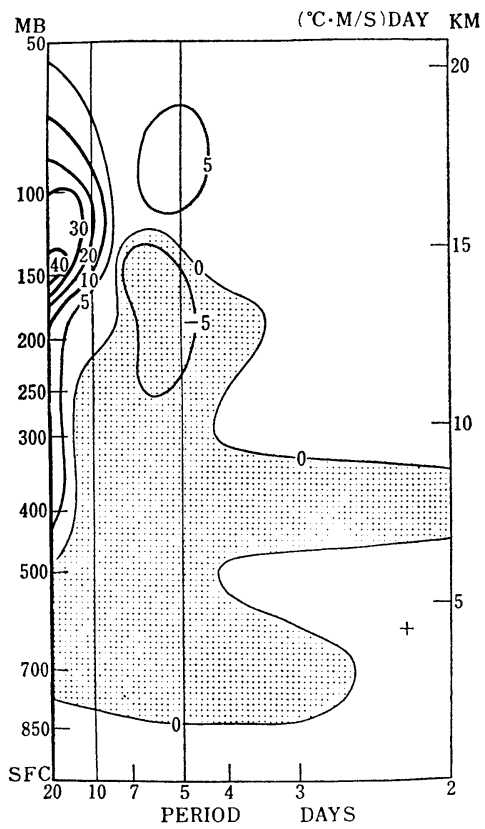

PALMYRA-MAJURO-KWAJALEIN

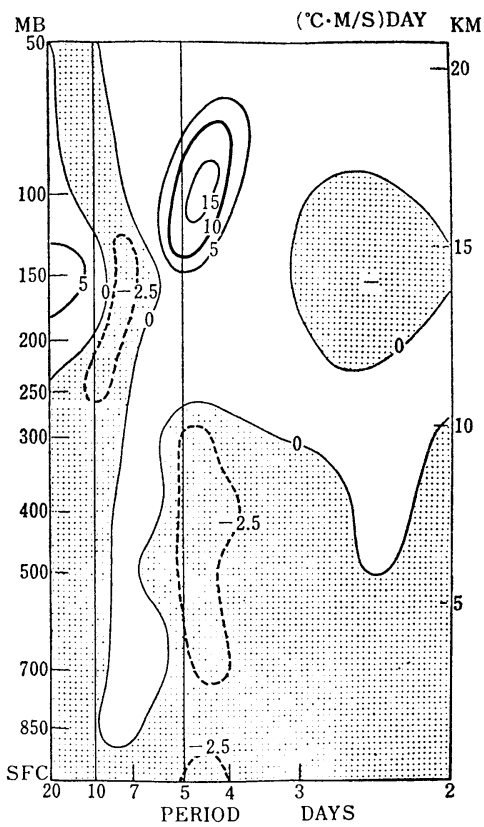

Fig. 2. Average co-spectra between $T$ and $v$ in the sub-tropical region (left) and those in the equatorial region (right).

These differences may be related to the difference of the characteristics of disturbances between the eastern Pacific and the western Pacific as noted by Nitta (1970). But the general features of the co-spectra are almost the same, so that we average the co-spectra without considering the longitudinal difference of the stations. Since the latitude of Christmas $\left(2^{\circ} \mathrm{N}, 157^{\circ} \mathrm{W}\right)$ is somewhat different from those of three stations mentioned above and the data at constant pressure levels at the station are not so good, we exclude the data at Christmas. We also average the co-spectra at Hilo $\left(20^{\circ} \mathrm{N}\right.$, $\left.155^{\circ} \mathrm{N}\right)$, Lihue $\left(22^{\circ} \mathrm{N}, 159^{\circ} \mathrm{W}\right)$, Johnston $\left(17^{\circ} \mathrm{N}\right.$, $\left.170^{\circ} \mathrm{W}\right)$ and Wake $\left(19^{\circ} \mathrm{N}, 167^{\circ} \mathrm{E}\right)$ as another group representing the sub-tropical latitudes near $20^{\circ} \mathrm{N}$.

Fig. 1 illustrates the average co-spectra between $u$ and $v$ in the equatorial and the sub-tropical latitudes. The average co-spectra near $20^{\circ} \mathrm{N}$ (left) show two positive peaks, $i$. $e$. disturbances with periods of about 6 days and those with periods longer than 10 days transport the momentum northward. The poleward momentum flux due to these disturbances becomes maximum at about $200 \mathrm{mb}$. On the other hand, the average cospectra near the equator (right) show that disturbances with periods of about 4 days also play an important role in the $u-v$ correlation. In the middle troposphere contributions due to the 4-day period disturbances are relatively larger than those due to the other disturbances. The 4-day period disturbances also transport zonal momentum poleward. In the equatorial upper troposphere, contributions of disturbances with periods of about 6 days and those with periods longer than 10 days are also large. It is interesting that the 6-day period disturbances have a negative correlation between $u$ and $v$.

Fig. 2 shows the average co-spectra between $T$ and $v$ in the equatorial and the sub-tropical regions. The average co-spectra near $20^{\circ} \mathrm{N}$ (left) show that there are large positive correlations in the period range longer than 10 days in the upper troposphere and in the lower stratosphere, and small negative correlations in the period range near 6 days centered around the 200-mb level. On the other hand, contributions due to 4-5 day period disturbances dominate in the equatorial region (right). The estimates of $C(T, v)$ due to the 4-5 day period disturbances are negative in the lower troposphere and are positive in the upper troposphere and in the lower stratosphere. 


$$
\mathrm{C}(\phi, v)
$$

LIHUE-HILO-JOHNSTON-WAKE

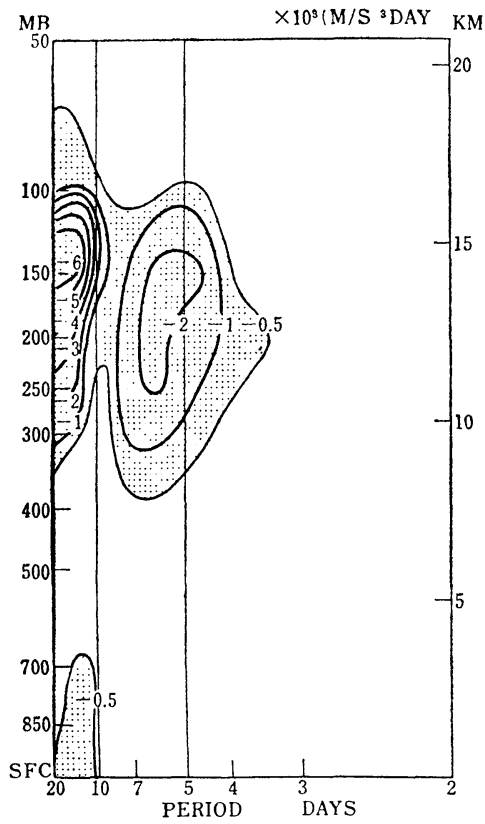

PALMYRA-MAJURO-KWAJALEIN

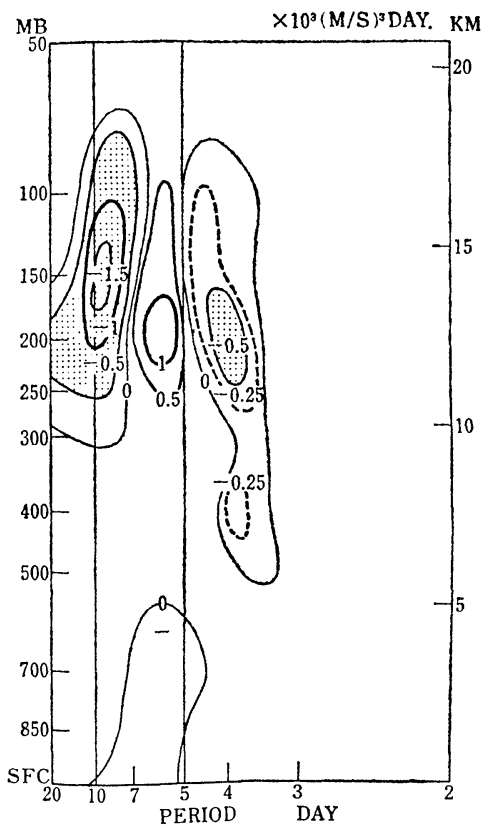

Fig. 3. Average co-spectra between $\phi$ and $v$ in the sub-tropical region (left) and those in the equatorial region (right).

There is a sharp positive peak of $C(T, v)$ near the $100-\mathrm{mb}$ level. In addition to the 4-5 day disturbances, positive correlations between $T$ and $v$ in the period range longer than 10 days and negative correlations in the period range near 7 days also exist in the upper troposphere.

Fig. 3 shows co-spectra between geopotential height and meridional wind velocity. In the average co-spectra near $20^{\circ} \mathrm{N}$ (left), there are large negative $C(\phi, v)$ both in the period range longer than 10 days and in the period range near 6 days in the upper troposphere. The estimates of $C(\phi, v)$ in the other period range are very small. On the other hand, for the average cospectra near the equator (right), contributions of disturbances with periods of about 4 days are relatively large in the whole troposphere. $C(\phi$, $v$ ) due to the 4-day disturbances are negative in the middle and upper troposphere, showing the equatorward energy flux. The equatorward energy flux due to the 4- to 5-day period disturbances in the upper troposphere has been obtained by Yanai and Hayashi (1969) and the values of $C(\phi, v)$ obtained by them are almost the same order as those obtained in this study. They obtained $\overline{\phi v}$ from the data of $u, v$ and $T$ by the use of linearized equations of motion but we calculated $\overline{\phi v}$ directly from the data of geopotential height and meridional wind velocity. In addition to the contribution due to the 4-day period disturbances, contributions due to disturbances with periods near 6 days and those with periods near 10 days are dominant in the upper troposphere. The 6-day period disturbances transport energy poleward and the 10-day period disturbances transport energy equatorward.

Comparing Fig. 3 with Fig. 1, we find that $C(\phi, v)$ and $C(u, v)$ are negatively correlated especially in the upper troposphere. The energy flux of the long quasi-geostrophic waves which propagate with a phase velocity $c$ is given by the following expression.

$$
\bar{\phi} \bar{v}=-(U-c) \overline{u v},
$$

where $U$ is the velocity of the zonal current. The equation (1) is a slight extension of the formula obtained by Eliassen and Palm (1961). From the knowledge of $C(\phi, v)$ and $C(u, v)$ and that of $U$, we can estimate an average phase velocity of the disturbances using (1). We use integrated values of $C(\phi, v)$ and those of $C(u, v)$ in the three period ranges near the certain period to 
Table 2. Phase velocity and the corresponding wavelength of various disturbances at the 200-mb level estimated from the relation between $\overline{u v}$ and $\overline{\phi v}$.

(a) Subtropical region $U=17 \mathrm{MS}^{-1}$

\begin{tabular}{c|c|c||c|c|c}
\hline PERIOD RANGE (DAYS) & $\overline{u v}\left(\mathrm{M}^{2} \mathrm{~S}^{-2}\right)$ & $\overline{\phi v}\left(\mathrm{M}^{3} \mathrm{~S}^{-3}\right)$ & $U-c\left(\mathrm{MS}^{-1}\right)$ & $c\left(\mathrm{MS}^{-1}\right)$ & $\begin{array}{c}\text { WAVE LENGTH } \\
(\mathrm{KM})\end{array}$ \\
\hline $12.50 \sim 16.67$ & 6.76 & -150 & 22 & -5 & 7,000 \\
\hline $5.59 \sim 7.14$ & 8.63 & -106 & 12 & 5 & 3,000 \\
\hline
\end{tabular}

(b) Equatorial region $\quad U=8 \mathrm{MS}^{-1}$

\begin{tabular}{c|c|c||c|c|c}
\hline PERIOD RANGE (DAYS) & $\overline{u v}\left(\mathrm{M}^{2} \mathrm{~S}^{-2}\right)$ & $\overline{\phi v}\left(\mathrm{M}^{3} \mathrm{~S}^{-3}\right)$ & $U-c\left(\mathrm{MS}^{-1}\right)$ & $c\left(\mathrm{MS}^{-1}\right)$ & $\begin{array}{c}\text { WAVE LENGTH } \\
(\mathrm{KM})\end{array}$ \\
\hline $8.33 \sim 12.50$ & 1.81 & -50.5 & 28 & -20 & 17,000 \\
\hline $5.56 \sim 7.14$ & -1.47 & 58.1 & 40 & -32 & 17,000 \\
\hline $3.85 \sim 4.55$ & 0.78 & -29.8 & 38 & -30 & 11,000 \\
\hline
\end{tabular}

obtain $\overline{\phi v}$ and $\overline{u v}$.

Table 2 shows the phase velocity and the corresponding wavelength of various disturbances estimated in this way at the $200-\mathrm{mb}$ level. In the equatorial region, three disturbances with periods of about 4, 6 and 10 days have westward phase velocities relative to the mean zonal wind. The estimated wavelength of the 4-day period disturbances agrees well with the previous estimate of Yanai et al. (1968). In the sub-tropical region, both disturbances with 6-day periods and 15-day periods have westward phase velocities relative to the mean zonal wind but the 6-day periods disturbances propagate eastward and have a wavelength of about $3,000 \mathrm{~km}$. The longer period disturbances have a large wavelength and westward phase velocity. In the lower troposphere, the amplitudes of $C(u, v)$ and $C(\phi, v)$ are small and the correlation between them are not so high. Therefore it is difficult to apply the method mentioned above to the lower tropospheric disturbances.

From the above results we conclude that disturbances with 4-5 day periods play an important role in the horizontal transports of momentum, sensible heat and potential energy in the equatorial region. On the other hand disturbances with periods longer than 6 days have large contributions to the horizontal transports at the subtropical latitudes. The disturbances with 4-5 day period in the upper troposphere and lower stratosphere in the equatorial region correspond to large-scale waves studied by Yanai and Maruyama (1966), Maruyama (1967, 1968 a, b), and Yanai and Hayashi (1969). The 4-5 day period disturbances in the lower troposphere were fully examined by Nitta (1970). The negative correlation between $T$ and $v$ due to the low-level disturbances is consistent with their thermal structure $i$. $e$., a cold air is situated to the east of trough axis and a warm air to the west. Besides these disturbances, disturbances with longer periods also predominate in the equatorial upper troposphere but the characteristics and the structure of these longer period disturbances are not well known. Recently, Yanai and Murakami (1970) have examined the structure of various wave modes which exist in the equatorial region by separating the spectral contributions into the symmetric and antisymmetric parts with respect to the equator. The 6-day period disturbances contributing to the horizontal transports in the sub-tropical upper troposphere may correspond to the travelling trough extending from middle latitudes. The longer period disturbances in the subtropics may be a kind of long Rossby-type waves.

\section{The total eddy horizontal transports of zonal momentum, sensible heat and potential energy and contributions of 4-5 day disturbances}

We shall next examine the total eddy horizontal transports of zonal momentum, sensible heat and potential energy and the contributions of disturbances in the period range near 4 days to the total horizontal transport as functions of latitude and altitude. The total eddy horizontal transport in our analysis contains contributions due to all disturbances with periods less than 20 days. Among them the horizontal transport due 
to disturbances in the frequency range from 0.18 to $0.32 \mathrm{day}^{-1}, i . e$. , in the period range from 5.56 to 3.12 days are given by

$$
\sum_{f=0.18}^{f=0.32} C_{f}(A, v) \Delta f
$$

where $A$ may be $u, T$ or $\phi$, and $\Delta f=0.02$ day $^{-1}$. Since we use time series data at only 13 stations, we cannot obtain detailed latitude-height distributions of $\overline{u v}, T \bar{v}$ and $\overline{\phi v}$. So we divide the whole data into three latitudinal groups and obtain average values for each latitudinal belt. We divide the tropical regions into $15^{\circ} \mathrm{S}$-Equator, Equator $-15^{\circ} \mathrm{N}$ and $15^{\circ} \mathrm{N}-30^{\circ} \mathrm{N}$. Since the data of Midway $\left(28^{\circ} \mathrm{N}, 177^{\circ} \mathrm{N}\right)$ have somewhat different characteristics from those of other stations in the similar latitudes, they are omitted. We divide the troposphere vertically into three layers. The lower layer includes the 1000-, 850- and $700-\mathrm{mb}$ levels, the middle layer the 500-, 400- and $300-\mathrm{mb}$ levels and the upper layer the 250-, 200-, 150and $100-\mathrm{mb}$ levels.

Fig. 4 shows the latitudinal-height distributions of the total eddy transport of zonal momentum and the partial transport due to the 4-day period disturbances. The total momentum transport is directed poleward in all the subdomains. Strong poleward fluxes exist in the upper troposphere especially in the region between $15^{\circ} \mathrm{N}$ and $30^{\circ} \mathrm{N}$. The estimated values of the momentum flux agree well with those due to

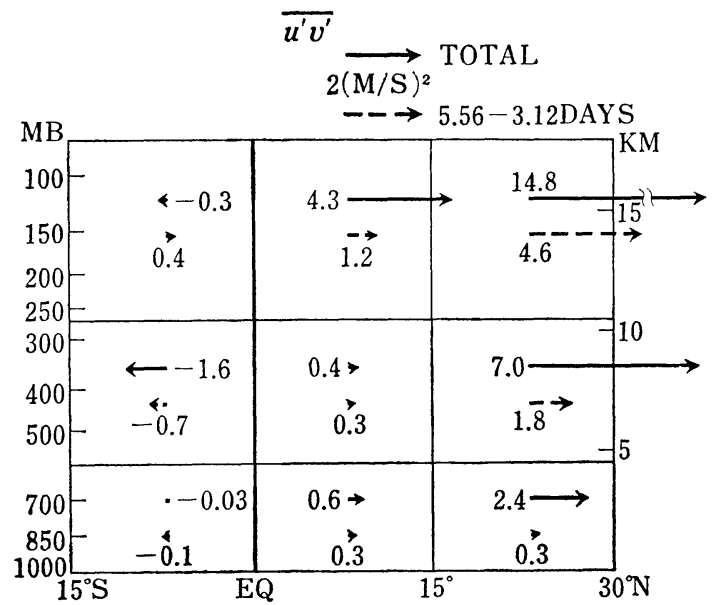

Fig. 4. Latitude-height distributions of horizontal transports of zonal momentum due to the total transient eddies and those due to the 4-5 day period disturbances.

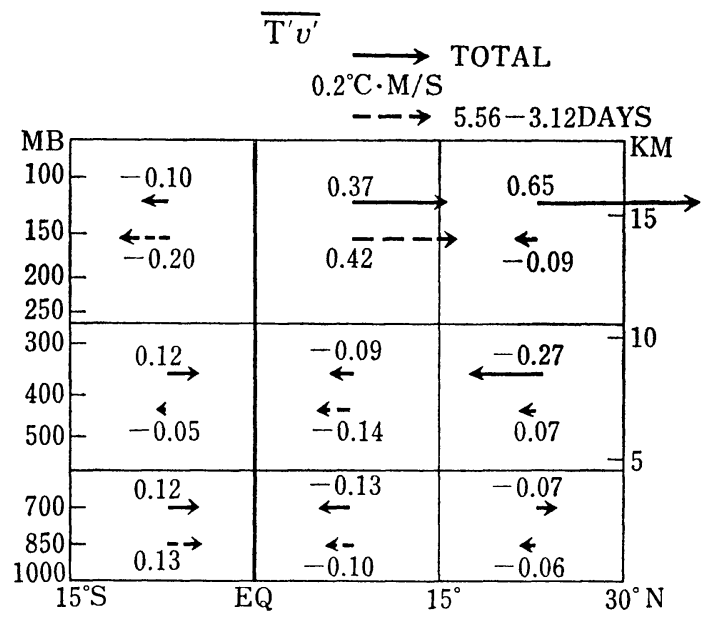

Fig. 5. Latitude-height distributions of horizontal transports of sensible heat due to the total transient eddies and those due to the 4-5 day period disturbances.

transient eddies obtained by Kidson et al. (1969). There is an indication showing momentum fluxes across the equator from the winter hemisphere to the summer hemisphere in the upper troposphere as noted by Kidson et al. (1969). The direction of the zonal momentum flux due to the 4-day period disturbances is generally the same with that of the total eddy transport. However, the magnitude of the transport due to the 4-day period disturbances is very small compared with that of the total eddy transport in the subtropical region $\left(15^{\circ} \mathrm{N}-30^{\circ} \mathrm{N}\right)$. The ratio of the partial transport due to the 4-day period disturbances to the total eddy transport is about $1 / 4 \sim 1 / 5$ in the subtropical region. In the equatorial region $\left(15^{\circ} \mathrm{N}-15^{\circ} \mathrm{S}\right)$ the momentum transport due to the 4-day period disturbances become even smaller but its ratio to the total eddy momentum transport is large especially in the lower and the middle layers.

Fig. 5 shows the distributions of the total eddy transport of sensible heat and the partial transport due to the 4-day period disturbances. As for the total eddy transport, there is a small and equatorward flux in the lower and middle troposphere and there is a large and poleward flux in the upper troposphere. Starr and Wallace (1964) and Kidson et al. (1969) obtained the equatorward heat flux in the tropical troposphere. The estimates of the equatorward heat fluxes in our study are somewhat smaller than those obtained by them. A large part of the sensible heat fluxes 


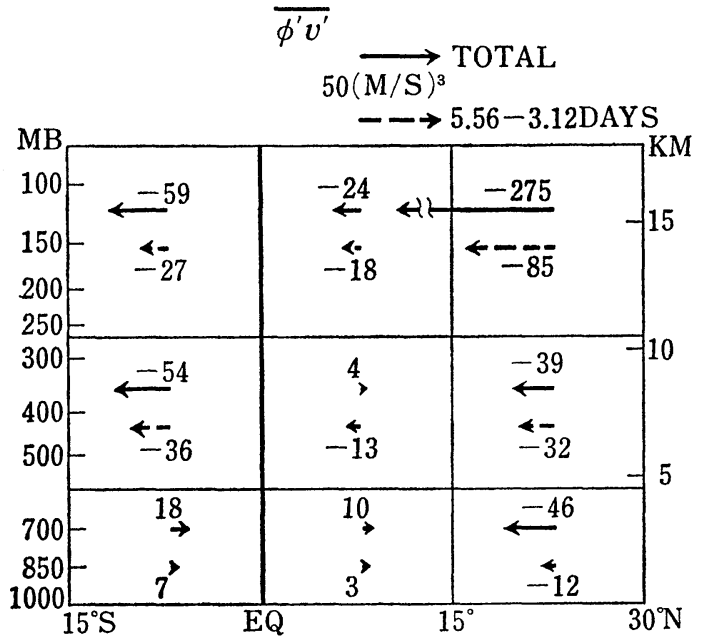

Fig. 6. Latitude-height distributions of horizontal transports of potential energy due to the total transient eddies and those due to the 4-5 day period disturbances.

in the equatorial region are due to disturbances with periods near 4 days. These 4-to 5-day period disturbances have a positive correlation between $T$ and $v$ in the upper troposphere and the lower stratosphere as noted by Maruyama (1968b) and Yanai and Hayashi (1969), and have a negative correlation in the lower troposphere as studied by Nitta (1970).

Finally we examine the horizontal transport of potential energy. In Fig. 6 we notice that a remarkably large energy flux is introduced from higher latitude especially in the upper troposphere and that the flux is southward across the equator, $i$. $e$., the energy is flowing from the summer hemisphere to the winter hemisphere. Mak (1969) also obtained a strong equatorward energy flux from the higher latitudes. The order of the flux estimated in our analysis is in good agreement with that obtained by Mak (1969). A large part of contributions to the equatorward energy flux are due to longer period disturbances. Though the disturbances with 4-5 day periods contribute little to the equatorward energy flux, the direction of energy flux due to these disturbances is same as that of the total energy flux.

\section{Estimates of energy transformations}

In this section we shall estimate energy transformations associated with transient eddies in the equatorial region. As disturbances with periods of about 4 days dominate in the equatorial region as mentioned in the preveous sections, we shall examine the energy balance for this particular period range. We assume that the wave disturbances with a certain periodicity propagate in the east-west direction without changing their amplitude. From linearized equations of motion and the first law of thermodynamics we can derive the following energy equations.

$$
\begin{gathered}
\frac{\partial \bar{k}}{\partial t}+\frac{\partial}{\partial y}(\overline{\phi v})+\frac{\partial}{\partial p}(\bar{\phi} \bar{\omega})=-\frac{\partial U}{\partial p} \overline{u v} \\
-\frac{\partial U}{\partial p} \bar{u} \bar{\omega}-\alpha \bar{\omega} \\
\frac{\partial \bar{e}}{\partial t}=-\frac{\frac{\partial \bar{\alpha}}{\partial y}}{\sigma^{*}} \overline{v \alpha}+\alpha \bar{\omega}+\frac{R}{c_{p} \sigma^{*} p} \alpha \frac{d Q}{d t}
\end{gathered}
$$

where $k \equiv \frac{1}{2}\left(u^{2}+v^{2}\right)$ and $e \equiv \frac{1}{2 \sigma^{*}} \alpha^{2}$ are the eddy kinetic energy and the eddy available potential energy respectively, $\omega \equiv \frac{d p}{\partial t}$ the vertical $p$-velocity, $U$ the basic mean zonal current, $\bar{\alpha}$ the mean specific volume, $\sigma^{*}$ the mean static stability defined by $\sigma^{*}=--\frac{1}{\bar{\theta}} \frac{\partial \bar{\theta}}{\partial p}, \frac{d Q}{d t}$ the diabatic heating per unit mass of air per unit time, $c_{p}$ the specific heat of air at constant pressure and $R$ the gas constant of air. Small letters denote quantities of disturbances and bars over letters denote time means. For diagnostic purposes, we may assume that $\partial \bar{k} / \partial t$ and $\partial \bar{e} / \partial t$ are zero, $i$. e., the average kinetic energy and temperature variance with eddies are constant with time. The second and the third terms on the left hand side of equation (2) show the divergence of wave energy flux, the first and the second terms on the right hand side of (2) denote the energy conversions from the mean zonal wind and the last term is the energy conversion from eddy potential energy to eddy kinetic energy. In equation (3), the first, the second and the third terms on the right hand side are energy conversions from mean potential energy, the energy conversion from eddy kinetic energy and the generation of eddy potential energy due to diabatic heating respectively. In our spectral analysis, we cannot measure the vertical velocity and the diabatic heating, so that we cannot obtain terms containing $\bar{\phi} \bar{\omega}, \overline{u \omega}, \bar{\alpha} \bar{\omega}$ and $\overline{\alpha \frac{d Q}{d t}}$. We can estimate only terms of 


$$
\begin{aligned}
\left(K_{z}, K_{E}\right) & \equiv-\frac{\partial U}{\partial y} \overline{u v},\left(A_{z}, A_{E}\right) \equiv-\frac{1}{\sigma^{*}} \frac{\partial \bar{\alpha}}{\partial y} v \bar{\alpha} \\
& \equiv-\frac{1}{\sigma^{*}}\left(\frac{R}{p}\right)^{2} \frac{\partial T}{\partial y} T \bar{v} \text { and } \frac{\partial}{\partial y}(\overline{\phi v}) .
\end{aligned}
$$

Fig. 7 shows latitudinal distributions of mean zonal wind for the analyzed period in the three layers. Black circles denote station values of mean zonal wind in the eastern Pacific area (to the east of $180^{\circ}$ ) and white circles denote those in the western Pacific area (to the west of $180^{\circ}$ ). In the east Pacific, the velocity distributions are nearly symmetric with respect to the equator in the lower and the middle troposphere and the mean wind shows positive $\partial U / \partial y$ in the upper troposphere. The latitudinal variation of the zonal wind appears to be different between the eastern and the western Pacific areas, but the data near the equator in the western Pacific are missing and it is difficult to measure the horizontal shear in the western Pacific. Fig. 8 shows latitudinal distributions of mean temperature for the same period in the three layers. In the lower and the middle troposphere the temperature is maximum at the equator but in the upper troposphere the mean temperature is almost constant.

We can estimate $\left(K_{z}, K_{E}\right)$ and $\left(A_{z}, A_{E}\right)$ from the knowledge of $u v$ and $T v$ due to eddies which were obtained in Section 4 and the meridional gradient of mean zonal wind and that of mean temperature. We also obtain $-\frac{\partial}{\partial y}(\overline{\phi v})$ from the estimated values of $\phi \bar{v}$. We calculate these quantities in the region between the equator and $15^{\circ} \mathrm{N}$. In this computation we use the values of $\partial U / \partial y$ in the eastern Pacific because the data

$\overline{\mathrm{U}}$
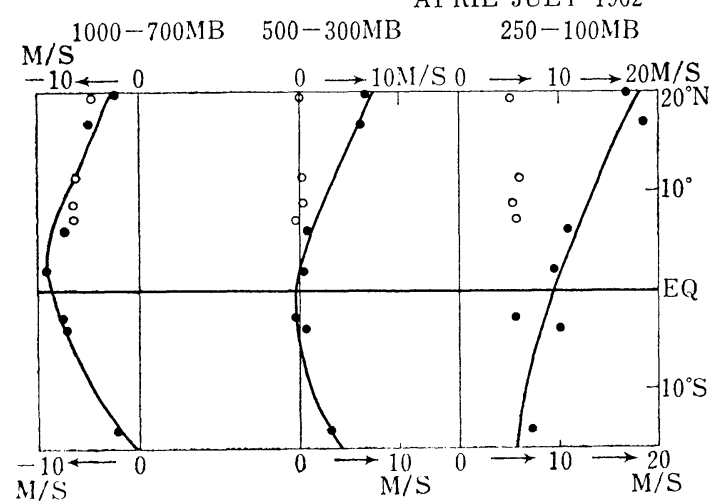

Fig. 7. Latitudinal distributions of the mean zonal wind.
$1000-700 \mathrm{MB} \quad 500-300 \mathrm{MB} \quad 250-100 \mathrm{MB}$

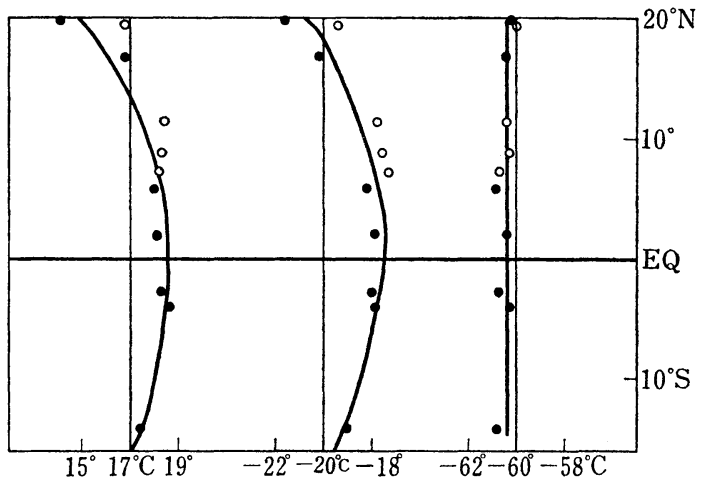

Fig. 8. Latitudinal distributions of the mean temperature.

ENERGY TRANSFORMATIONS $\times 10^{-2}$ ergs $\mathrm{s}^{-1} \mathrm{gm}^{-1}$

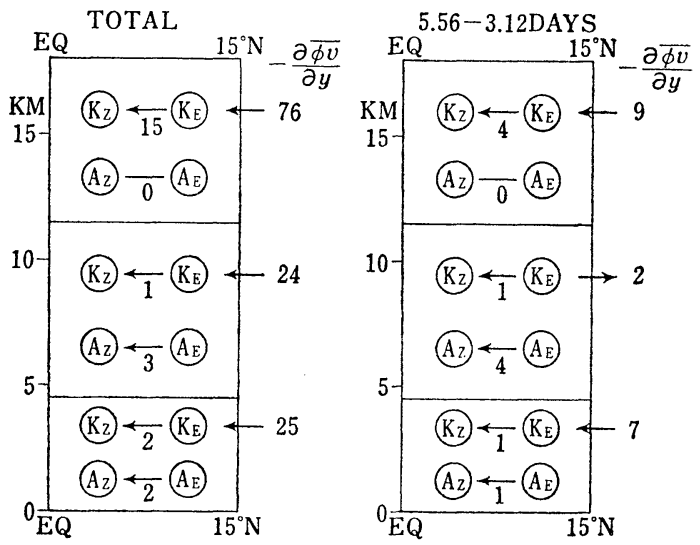

Fig. 9. Energy transformations due to the total transient eddies (left) and those due to the 4-5 day period disturbances (right).

near the equator in the western Pacific are missing. Fig. 9 illustrates energy transformation, $\left(K_{Z}, K_{E}\right)$, $\left(A_{z}, A_{E}\right)$ and $-\frac{\partial}{\partial y}(\overline{\phi v})$, due to the total transient eddies which contain all eddies with periods shorter than 20 days and those due to disturbances in the period range near 4 days. For the total eddies, we notice that the convergence of energy flux from side boundaries is quite large especially in the upper troposphere. This result agrees with that shown by Mak (1969). Values of $-\frac{\partial}{\partial y}(\overline{\phi v})$ are almost one order of magnitude larger than those of $\left(K_{z}, K_{E}\right)$ and 
those of $\left(A_{z}, A_{E}\right) . \quad\left(K_{z}, K_{E}\right)$ and $\left(A_{z}, A_{E}\right)$ are generally negative, $i$. $e$., the eddy kinetic energy is transformed to the mean kinetic energy and the eddy available potential energy is transformed to the mean available potential energy because both the momentum and the sensible heat flux are counter-gradient. Kidson et al. (1969) obtained energy conversions from eddy to mean kinetic energy by the transient eddies in the summer hemisphere. The estimated values of $\left(K_{Z}, K_{E}\right)$ are on the summer hemisphere. The estimated values of $\left(K_{z}, K_{E}\right)$ are on the same order of magnitude with those of Kidson et al. (1969). Krishnamurti (1969) obtained conversions from eddy to zonal kinetic energy in the vicinity of the intertropical convergence zone. The values of $\left(A_{2}, A_{E}\right)$ obtained in our analysis and those in Kidson et al. (1969) are also on the same order of magnitude but the direction of energy conversion is opposite. They obtained energy conversions from zonal available potential energy to eddy available potential energy in the summer hemisphere. Manabe and Smagorinski (1967) and Krishnamurti (1969) also obtained energy conversions from zonal to eddy available potential energy in their numerical experiments. In all of these studies, the sensible heat flux was downgradient contrary to the present analysis.

General features of $\left(K_{z}, K_{E}\right)$ and $\left(A_{z}, A_{E}\right)$ due to disturbances with periods near 4 days are similar to those of the total eddies, i. e., $\left(K_{Z}, K_{E}\right)$ and $\left(A_{z}, A_{E}\right)$ are negative, but the values of $\left(K_{Z}, K_{E}\right)$ due to these disturbances in the upper troposphere are smaller than those of $\left(K_{Z}, K_{E}\right)$ due to the total eddies. The convergence of energy flux from the side boundaries due to the 4-day period disturbances exist in the lower and the upper troposphere, but its relative importance to the energy balance is small as compared with that for the total eddies. In the middle troposphere divergence of energy flux from the side boundaries is noticed.

Since we have no direct measurements of $\left(A_{Z}, A_{E}\right) \equiv-\overline{\alpha \omega}$, what can be said with certainty is that the energy flux from higher latitudes acts as a source of eddy kinetic energy in the $0^{\circ}-15^{\circ} \mathrm{N}$ region. The energy cycle obtained in this study is very similar to that obtained by Mak (1969).

\section{Conclusions and remarks}

Firstly we calculated average co-spectra between $u$ and $v, T$ and $v$, and $\phi$ and $v$ for equatorial and subtropical Pacific stations based on the data of April-July 1962 and examined time scales of disturbances which contribute to the horizontal transports of zonal momentum, sensible heat and potential energy. In the equatorial region disturbances with periods of about 4 days play an important role to the meridional transports in the whole troposphere, but disturbances with periods of about 6 days and those with periods longer than 10 days also contribute to the transports in the upper troposphere. On the other hand, in the subtropical region disturbances in the period range near 6 days and those with periods longer than 10 days have large contributions to the horizontal transports. The nature of these disturbances was infered from the relation between $\overline{u v}$ and $\overline{\phi v}$. All wave modes show westward phase propagation relative to the mean zonal current.

Secondly we obtained the total eddy transports of zonal momentum, sensible heat and potential energy due to transient eddies and examined the relative importance of the contributions of disturbances with periods of about 4 days to the total transports. The momentum flux is directed poleward in all the sub-domains and large poleward momentum flux exists in the upper troposphere between $15^{\circ} \mathrm{N}$ and $30^{\circ} \mathrm{N}$. The heat flux is directed equatorward in the lower and middle troposphere and poleward in the upper troposphere. A large part of the sensible heat flux in the equatorial region is due to disturbances with periods of about 4 days. A remarkably strong equatorward energy flux comes in from higher latitudes in the upper troposphere. This strong equatorward energy flux is mainly due to disturbances with periods longer than 6 days. Energy flux is directed southward across the equator.

Thirdly we made a partial estimate of the energy balance for the total eddies and that for the 4-to 5-day period disturbances. The convergence of energy flux entering from the subtropical latitudes is almost one order of magnitude larger than other energy transformations, $\left(K_{Z}, K_{E}\right)$ and $\left(A_{z}, A_{E}\right.$. The eddy kinetic energy is transformed to the zonal kinetic energy and the eddy available potential energy is transformed to the zonal available potential energy. The direction of energy transformations obtained in this study is very similar to that obtained by Mak (1969). Numerical studies of Manabe and Smagorinsky (1967) and Krishnamurti (1969) showed the importance of the generation of available potential 
energy which is due to condensation and convection and energy conversion from eddy available potential energy to eddy kinetic energy, but they did not discuss the boundary flux. In a recent numerical study using a global model, Manabe et al. (1970) demonstrated that the conversion of eddy available potential energy is the more important source than the energy transfer from the middle latitudes.

An observational study of the conversion through $-\overline{\alpha \omega}$ in the tropics and the convergence of energy flux from higher latitudes is being in progress by the author. We remark that the sign of $\partial U / \partial y$ in the western Pacific in 1958 was quite different from that in the eastern Pacific in 1962 (Nitta and Yanai, 1969). Further studies are also needed to clarify the contribution of barotropic processes.

It is obvious that the data samples utilized in this study are too small to establish a general conclusion about the role of eddies in the whole tropics. It is highly needed to expand the analysis to other areas and to other samlping periods.

\section{Acknowledgments}

The author wishes to express his thanks to Prof. M. Yanai for his guidance and suggestion throughout this work. The author also thanks Drs. I. Hirota and T. Maruyama for their valuable discussions. Thanks are extended to Miss I.T. Tamura for typing the manuscript. This study was supported by a Special Research Fund (GARP) from the Ministry of Education.

\section{References}

Eliassen, A., and E. Palm, 1961: On the transfer of energy in stationary mountain waves. Geofysiske Publikasjoner, 22, No. 3.

Iida, M., 1968: Computation of the transports of momentum, sensible and latent heat across the equator. Meteor. Soc., Japan., 46, 1-13.

Kidson, J.W., D.G. Vincent, and R.E. Newell, 1969: Observational studies of the general circulation of the tropics: long mean values. Quart. J. Roy. Meteor. Soc., 95, 258-287.

Krishnamurti, T.N., 1969: An experiment in numerical prediction in equatorial latitudes. Quart. J. Roy. Meteor. Soc., 95, 594-620.

Mak, M.K., 1969: Laterally driven stochastic motions in the tropics. J. Atmos. Sci., 26, 41-64.

Manabe, S., and J. Smagorinsky, 1967: Simulated climatology of a general circulation model with a hydrologic cycle. II. Analysis of the tropical atmosphere. Mon. Wea. Rev., 95, 155-169.

Manabe, S., J.L. Holloway, Jr., and H.M. Stone, 1970: Tropical circulation in a time integration of a global model of the atmoshere. J. Atmos. Sci., 27, (in press).

Maruyama, T., 1967: Large-scale disturbances in the equatorial lower stratosphere. J. Meteor. Soc. Japan., 45, 391-408.

, 1968a: Time sequence of power spectra of disturbances in the equatorial lower stratosphere in relation to the quasi-biennial oscillation. $J$. Meteor. Soc. Japan, 46, 327-342.

, 1968b: Upward transport of westerly momentum due to large-scale disturbances in the equatorial lower stratosphere. J. Meteor. Soc. Japan, 46, 404-417.

Nitta, Tsuoshi, 1970: Statistical study of tropospheric wave disturbances in the tropical Pacific region. J. Meteor. Soc. Japan., 48, 47-60.

barotropic instability of the tropical easterly current. J. Meteor. Soc. Japan, 47, 127-130.

Obasi, G.O.P., 1963: Poleward flux of atmospheric angular momentum in the southern hemisphere. J. Atmos. Sci., 20, 516-528.

Palmer, C.E., 1951: Tropical meteorology. Compendium of Meteorology, Amer. Meteor. Society, 859-880. , 1952: Tropical meteor
Roy. Meteor. Soc., 78, 126-163.

Riehl, H., 1945: Waves in the easterlies and the polar front in the tropics. Dept. Meteor. Univ. Chicago, Misc. Rept.,No. 17, 79 pp.

- 1948: On the formation of west Atlantic hurricanes. Dept. Meteor. Univ. Chicago, Misc. Rept., No. 24, 1-64.

, 1954: Tropical Meteorology. McGraw Hill, 392 pp.

Starr, V.P., and R.M. White, 1952a: Meridional flux of angular momentum in the tropics. Tellus, 4, 118-125.

$\longrightarrow$, and 1952b: Two years of momentum flux data for $31^{\circ} \mathrm{N}$. Tellus, 4, 332-333. - and - — 1954: Two years of momentum flux data for $13^{\circ} \mathrm{N}$. Tellus. 6, 180181 .

-, and J.M. Wallace, 1964: Mechanics of eddy processes in the tropical troposphere. Pure and Applied Geophysics, 58, 138-144.

Tucker, G.B., 1965: The equatorial tropospheric wind regime. Quart. J. Roy. Meteor. Soc., 91, 140-150.

Wallace, J. M., and C.P. Chang, 1969: Spectrum analysis of large-scale wave disturbances in the tropical lower troposphere. J. Atmos. Sci., 26, 1010-1025.

Yamasaki, M., 1969: Large-scale disturbances in a conditionally unstable atmosphere in low latitudes. 
Papers in Meteor. Geophys., 20, (in press).

Yanai, M., 1961: Dynamical aspects of typhoon formation. J. Meteor. Soc. Japan, 39, 282-309.

wave disturbances propagating over the equatorial pacific. J. Meteor. Soc., Japan, 44, 291-294.

$\longrightarrow$, Tsuyoshi Nitta and

Y. Hayashi, 1968: Power spectra of large-scale disturbances over the tropical Pacific. J. Meteor.
Soc. Japan, 46, 308-323.

, and Y. Hayashi, 1969: Large-scale equatorial waves penetrating from the upper troposphere into the lower stratosphere. J. Meteor. Soc. Japan, 47, 167-182.

, and M. Murakami, 1970: Spectrum analysis of symmetric and antisymmetric equatorial waves. To be published.

\title{
熱帯対流圈における移動性擾乱の役割
}

\author{
新田就 \\ 東京大学理学部地球物理学教室
}

1962年の 4 月〜 7 月太平洋のデータをスペクトル解析し，熱帯対流圈において，風の南北成分と，その他の物理量 （風の東西成分，温度，ジオポテンシャル）との covariance（共分散）に果す擾乱の役割を調べた。赤道近くの領域 では，約 4 日周期の擾乱が covariance に大きな役割を果している。一方亜熱帯地域 $\left(20^{\circ} \mathrm{N}\right.$ 附近）では，約 6 日周 期の擾乱と，10日以上の擾乱が重要な役割を果している.

移動性擾乱による運動量輸送，顕熱輸送，ポテシャルエネルギ一輸送の緯度，高さに関する平均分布，及び，4日 周期の挸乱が輸送に果す寄与を調べた。周期 6 日以上の擾乱によつて, 高緯度から低緯度へ強いエネルギーの流れが ある. この結果は, Mak (1969) の結果と一致する. 対流圈下層, 中層には, 赤道方向の顕熱の流れがあり, 対流圏 上層では，強い極方向の顕熱輸送がある。輸送に対する 4 日周期の擾乱の寄与は高緯度側では小さいが, 低緯度側で は大さい。

赤道と $15^{\circ} \mathrm{N}$ 間の領域に批りる擾乱のエネルギ一变換の一部を見つもつた。高緯度側から低緯度側へ強いエネルギ 一の収束（気圧による仕事）があり, 擾乱の運動エネルギーは平均流の運動エネルギーに, 擾乱の有効位置エネルギ 一は, 平均場の有効位置エネルギーに変換される，高緯度側からのエネルギーの収束量は，擾乱から平均流への運動 エネルギーの変換量, 擾乱から平均場への有効位置エネルギーの変換量よりも一ケタ大きい. 